\title{
The Relationship between Emotional Intelligence and Affective Commitment: An Examination of Police Officers
}

\author{
Rogis Baker, Amar Hisham Jaaffar, Hasimi Sallehuddin, Mohamed Ayyub Hassan, Rosmah \\ Mohamed
}

\begin{abstract}
This paper examines the four dimensions of emotional intelligence: self-emotional appraisal (SEA), other's emotional appraisal (OEA), use of emotions (UOE) and regulation of emotions (ROE) in predicting effective commitment. The sample used for this study consisted of 372 police officers selected from five contingents: Kuala Lumpur, Selangor, Johor, Sabah and Sarawak. Testing our hypotheses in the field, we found strong evidence that the four dimensions of emotional intelligence: SEA, OEA, UOE and ROE enhance affective commitment. Additionally, the study provides evidence for the government to improve service quality and commitment to the police force.
\end{abstract}

Index Terms: Emotional Intelligence; Affective Commitment; Police Officer.

\section{INTRODUCTION}

Emotional intelligence refers to the ability of individuals to control their emotions effectively and positively influence relationships with others $\left[{ }^{\mathrm{i}}\right]$. While affective commitment is an adjunct to employee behavior and emotion within an organization $\left[{ }^{\mathrm{ii}},{ }^{\mathrm{iii}}\right]$, emotional intelligence and affective commitment are two elements that are often associated with individual emotions [ii, $\left.{ }^{\text {iv }}\right]$. These two factors are often discussed and have been the main focus of researchers of organizational behavior [iv].

The Royal Malaysian Police (PDRM) is the main law enforcement agency in the country and is regularly scrutinized and assessed by the public $\left[{ }^{\mathrm{V}},{ }^{\mathrm{vi}} \mathrm{vii}\right]$. The carrying out of policing duties to enforce the law, ensuring public safety and dealing with high risk, life-threatening situations has made this career unique and different from all other public services [ $\left.{ }^{\text {viii }}\right]$. The policing profession is a career area that is often associated with highly stressful work [ $\left.{ }^{\mathrm{ix}}\right]$. Previous studies have shown that increased work stress can cause a decline in the level of commitment and work

Revised Manuscript Received on September 22, 2019.

Rogis Baker, Faculty of Defence Studies \& Management, Universiti Pertahanan Nasional Malaysia, 57000 Sungai Besi, Kuala Lumpur Malaysia rogis@upnm.edu.my.

Amar Hisham Jaaffar, College of Business Management \& Accounting, Universiti Tenaga Nasional, 26810 Muadzam Shah, Pahang, Malaysia.

Hasimi Sallehuddin, Faculty of Information Science \& Technology, Universiti Kebangsaan Malaysia, 43600 Bangi, Selangor, Malaysia.

Mohamed Ayyub Hassan: Faculty of Social Sciences and Humanities, Universiti Teknologi Malaysia, 81310 Skudai, Johor, Malaysia.

Rosmah Mohamed: Faculty of Economics and Management, Universiti Putra Malaysia, Serdang, 43400 Seri Kembangan, Selangor, Malaysia. performance among police officers $\left[{ }^{\mathrm{x} x},{ }^{\mathrm{i}}\right]$. The findings of the study conducted by [ix] found that police officers with high levels of emotional intelligence have a lower level of work stress than those with low levels of emotional intelligence. Psychological stress can also increase employee turnover and negatively affect organizational commitment $\left[{ }^{\mathrm{xii}}\right]$. Individuals who can not face high stress will often fail to control their emotions [ $\left.{ }^{\mathrm{xiii}}\right]$. Empirical studies have shown that work stress has a significant negative relationship with work commitment, especially affective commitment $\left[{ }^{\mathrm{xiv}},{ }^{\mathrm{xv}}\right]$. Emotional intelligence and work stress are two elements that are closely related [vi,ix]. Therefore, police officers need to have high emotional and mental strength, and endurance, to face the challenges of their daily working environment $\left[{ }^{\mathrm{xvi}}\right]$.

\section{A. Problem Statement}

The government has implemented various approaches to ensure the services provided by civil servants achieve the optimum level of commitment, these include: Key Performance Indicators (KPIs), the Government Transformation Program (GTP), the National Blue Ocean Strategy (NBOS) and the National Transformation 2050 $\left[{ }^{\mathrm{xvii}},{ }^{\mathrm{xviii}}{ }^{\mathrm{xix}}\right]$. Yet there is still dissatisfaction within the public concerning the delivery of services by these civil servants [xix]. The community places a lot of trust in police services so the services provided need to be responsive and empathetic [vii]. In the context of this study, the PDRM department was found to face challenges and complaints by the public regarding inefficiencies in its service delivery [v].

Based on the statistics of the Public Complaints Bureau (BPA), the Prime Minister's Department for a period of 5 years (2013-2017) found that the PDRM was the Federal Government agency which received the highest number of complaints for five consecutive years. The most common complaints recorded by the BPA related to the quality of service, actions that did not address customer needs, failure to follow procedures, enforcement failures and unfair acts $\left[{ }^{\mathrm{xx}},{ }^{\mathrm{xxi}},{ }^{\mathrm{xxii}},{ }^{\mathrm{xxiii}},{ }^{\mathrm{xxiv}}\right]$. This number of recorded complaints suggests a crisis in commitment among police officers. Employees exhibiting low levels of commitment will tend to make mistakes in their daily tasks and cause a decline in job performance $\left[{ }^{\mathrm{xxv}},{ }^{\mathrm{xxi}}\right.$, xxvii $]$. The complaints and dissatisfaction of the community reflect a perceived negative performance assessment of these services [xviii].

Negative perceptions on the part of the community towards 
police services and the tarnished image of the department will affect the level of trust and cooperation with the police when carrying out their duties [ $\left.{ }^{\mathrm{xx} v i i i}\right]$. Customer satisfaction (or lack of it) is related to community expectations of police services and their reliability, responsiveness and empathy [vii]. Past studies have shown that work performance is influenced by emotional intelligence and work commitment factors $\left[{ }^{\mathrm{xxix}}\right]$. Therefore, high levels of emotional stability and commitment among police officers is important if they are to provide the best service to the community.

\section{LITERATURE REVIEW}

\section{A. The Concept of Emotional Intelligence}

Emotional intelligence is defined as the ability to precisely identify, assess, monitor and regulate the emotions of others and distinguish between them $\left[{ }^{\mathrm{xxx}}, \mathrm{i},{ }^{\mathrm{xxxi}}\right]$. According to $\left[{ }^{\mathrm{xxxii}}\right]$, emotional intelligence can be described as an interaction between shared thoughts and feelings in which individuals have the ability to realize, understand and manage their thoughts and behaviors and the thoughts and behaviours of others. Is this correct? It didn't make sense before.

The concept of emotional intelligence was introduced by [ $\left.{ }^{\mathrm{xx} x i i i}\right]$ who introduced the concept of emotional intelligence in oral and non-verbal form, emotional expression, emotional self-control and others and the control of emotions in decision-making. [Error! Bookmark not defined.] have suggested that emotional intelligence refers to a set of individual interrelated skills including the ability to see, evaluate and express feelings, the ability to explore and develop controlled emotions, the ability to understand emotions and emotional knowledge,e as well as the ability to control emotions to promote intellectual and emotional growth. $\left.{ }^{\text {xxxiv }}\right]$ also created a theory to explain the factors that affect one's emotions. The theory is known as The Theory of Emotional Intelligence. This theory describes the factors of failure and success in one's personal life, career and relationships as well as the emotional intelligence possessed by an employee [xxxiv]. He states that Intellectual Intelligence or IQ contributes only $20 \%$ to determining the success of one's life, while the other $80 \%$ of success is actually determined by emotional intelligence factors. In fact, performance among employees is closely related to their level of emotional intelligence $\left[{ }^{\mathrm{xxx}},{ }^{\mathrm{xxxvi}}\right]$. According to [xxxiv], an individual has two minds: the rational mind and emotional mind. [ $\left.{ }^{\mathrm{xx} x \mathrm{ii}}\right]$ also argues that a "well adjusted" person is one who is capable of controlling emotions. The concept of emotional intelligence inspired by [xxxiii] has been used by [ $\left.{ }^{\mathrm{xx} x \mathrm{vii}}\right]$ in introducing a conceptual model of emotional intelligence. This model views the concept of emotional intelligence as a diversity of non-cognitive factors, competence and skills that can affect an individual's ability to successfully face environmental challenges and pressures.

$\left[{ }^{\mathrm{xxxix}}\right]$ examined the level of emotional intelligence of two occupational groups, namely police officers and semi-professional staff in the field of mental health and child care. The findings of the study, [xxxix] found that the police officers had a higher level of emotional intelligence than any other profession. Police officers were able to understand their emotions and feelings, quickly adapt to stressful situations

and had the ability to deal with any pressure [xxxix]. In addition, empirical studies have also proven that emotional intelligence has a relationship with a variety of positive effects such as individual attitudes $\left[{ }^{\mathrm{xl}}\right]$, academic performance of students $\left[{ }^{\mathrm{xli}}\right]$, work attachment $\left[{ }^{\mathrm{xlii}}\right]$, sense of well-being in life $\left[{ }^{x l i i i}\right]$, reducing work stress $\left[{ }^{x l i v}\right]$ as well as enabling a person to deal with problems and emotions $\left[{ }^{\mathrm{xlv}}\right]$. In fact, emotional intelligence can even have a positive impact on organizations in areas such as organizational commitment $\left[{ }^{\text {xlvi }},{ }^{x l v i i}\right]$ and work performance $\left[{ }^{x l v i i i}, x x x v i,{ }^{x l i x}\right] .\left[{ }^{1}\right]$ has explained that emotional intelligence makes employees feel happier and more committed and increases the level of individual and organizational performance. Emotional intelligence is also seen as a psychosocial source of positive cognitive ability in humans and a driver of work engagement within an organization [xlii].

This study is based on the emotional intelligence model introduced by $\left.{ }^{\mathrm{li}}\right]$ which is derived from concepts inspired by [xxxiii]. [li] developed a simple psychometric emotional intelligence model that can be applied to management and leadership. According to [li], emotional intelligence has an impact on performance and job satisfaction, organizational commitment and employee support. [li] have also divided emotional intelligence into four components: self-emotional appraisal (SEA), other's emotional appraisal (OEA), use of emotions (UOE) and regulation of emotions (ROE).

\section{1) Self-Emotional Appraisal (SEA)}

According to [li], anyone who can understand the signals of anger can determine the best way to react to an angry person. SEA is an understanding of the meanings expressed through emotions that help individuals use interpersonal skills in the process of problem solving. The ability or inability to understand the emotions of oneself and others will positively or negatively affect relationships. Individuals who fail to understand certain feelings as they are presented will be unable to respond to feelings [Error! Bookmark not defined.,xxxi].

\section{2) Other's Emotional Appraisal (OEA)}

OEA is an individual's ability to perceive and understand the emotions of people around them [li]. Individuals who report high OEA scores can handle interpersonal relationships and have good relationships at work [ $\left.{ }^{\text {lii }}\right]$.

\section{3) Use of Emotions (UOE)}

UOE is the ability to have emotions and to use emotions in cognitive processes such as problem solving and help individuals to prioritize important things [li].This skill helps police officers use appropriate emotions when interacting with the community. This ability also helps employees to avoid dysfunctional feelings and adapt positive feelings that can be used to lessen frustration [liilii].

4) Regulation of Emotions (ROE).

According to [li], ROE is the individual ability to control the emotional signals that come from others. Individuals who are able to manage their emotions and others can increase their level of comfort in dealing with emotional situations. Individuals who are able to escape from a negative emotional state achieve the goal of individual emotional management

Bookmark [Error! 
defined.,xxxi].

Previous studies have proven that work stress issues and factors that contribute to stress at work can be overcome or reduced through an effective individual psychological approach which emphasizes the elements of emotional intelligence because both are related [xliv,xiii,ix,xlv]. In fact, emotional intelligence is found to negate work stress, depression, despair and suicidal ideation [xiii,xlv]. Individuals with high levels of emotional intelligence can face environmental challenges better than those with low emotional intelligence [xiii]. [liii] found that emotional intelligence has a positive relationship with the way of addressing tension and emotional problems.

Police are often exposed to interpersonal interactions involving emotional elements. They are required to deal with various incidents as a result of the community reporting cases such as death, illness, accidents and crime. Police claim that they always control their emotions and respond appropriately when dealing with a situation $\left[{ }^{\mathrm{liv}}\right]$ because, according to $\left[{ }^{\mathrm{lv}}\right]$, policing requires members to protect the community with a "customer-friendly" approach involving controlled emotional behaviour.

\section{B. Affective Commitment}

Affective commitment refers to the involvement of emotions and self-involvement (willingness) of conscientious members of an organization to achieve its goals [ii]. Affective commitment is also about emotional involvement based on positive feelings generated from worker engagement within the organization [ ${ }^{\text {lvi }}$, lvii $]$. [lvi] divided organizational commitment into three components, namely affective, continuous and normative. Affective commitment is based on emotional attachment, identification and engagement with the organization. Workers with high affective commitments will have a high level of loyalty towards their organization [lvi]. Employees with a continuous level of commitment are more likely to feel they should remain with an organization because of the cost implications if they leave the organization [lvi]. Normative commitment refers to a boundary or obligation to remain with an organization [lvi]. However, an employee can have all three components of commitment in different situations and circumstances [lvi].

Workers with strong affective commitment will stay with the organization because of their love and respect for the organization [ $\left.{ }^{\text {lviii }},{ }^{\text {lix }}\right]$ as opposed to the continuous commitment that is only essential, while normative commitment is more of a responsibility for the organization $\left[{ }^{\mathrm{lx}},{ }^{\mathrm{xi}},{ }^{\text {xii }}\right]$. In addition, affective commitment is a more effective way to measure affective commitment than the other two components [ii, ${ }^{\text {xiii }}$, ${ }^{\text {lxiv }}$ ]. Workers with high affective commitments will further enhance their involvement in work $\left[{ }^{\mathrm{lxv}}\right]$ and work performance [ $\left.{ }^{\mathrm{lxvi}},{ }^{\text {lxvii }}\right]$. In addition, there are past studies that use emotional elements, loyalty and psychological bonds to explain the meaning of employee commitment to the organization [ ${ }^{\text {lxviii }}$, lvii, $\left.{ }^{1 \mathrm{xix}}\right]$. Workers with a high level of commitment and dedication to work are often workers who work productively, have high job satisfaction, low absentee rates, workplace stability and organizational effectiveness [ ${ }^{1 \mathrm{x}}$ lxxi, $\left.\mathrm{xxv}\right]$. In fact, employees with high levels of commitment to an organization are also more likely to contribute in terms of innovation and creativity and thereby contribute to higher organizational capabilities [xxvi, ${ }^{1 \times x i i}$ ]. There has also been a meta-analysis of past studies that totaled 997 articles and showed that organizational commitment has a very strong relationship with work performance and, conversely, the intention to quit work [ $\left.{ }^{1 \mathrm{x} x i i i}\right]$.

\section{Impact of Emotional Intelligence on Affective Commitment}

Many scholars are now interested in studying how emotional intelligence can affect work outcomes such as organizational commitment [ ${ }^{\text {lxxiv }}$ ]. This is because emotional intelligence is an important factor in raising the level of commitment amongst employees [xviii]. In fact, a study conducted by $\left.{ }^{\mathrm{lxxv}}\right]$ shows that emotional intelligence has a significant positive relationship with changes in employee commitment to the organization.

The model of emotional intelligence is an internal construct that affects the individual's psychological well-being and their behavior at work [Error! Bookmark not defined., $\left.{ }^{1 \times x v i}, x x x i i\right]$. A study conducted by [ ${ }^{\text {lxxvii }}$ found that managers and employees who demonstrated high levels of emotional intelligence were able to create positive relationships between employees and thus affect their commitment to the organization. They also believe that emotional intelligence can have a positive impact on employee motivation where there is a positive relationship between the employer and the employee resulting from emotional intelligence factors. These, in turn, increase productivity and commitment amongst employees [lxxvii].

Most previous studies have found that enhancing interpersonal skills such as emotional intelligence can increase the level of affective commitment amongst employees [ ${ }^{\text {lxxviii }}{ }^{1 x x i x},{ }^{x}$ xiii, $\left.{ }^{1 \times x x}\right]$. Empirical studies have shown that emotional intelligence has a significant positive relationship with organizational commitment [xlvi,xvi,xlvii] and with affective commitment [ ${ }^{\text {lxxi }}$, lii, ${ }^{\text {lxxxii }}$,lxxviii,lxxix,xviii,lxxx,lxxiv]

This study examines the relationship between the emotional intelligence variables and the variables of affective commitment. Therefore, the hypotheses proposed in this study are:

$\mathrm{H}_{1}$ : The dimension of Self-Emotional Appraisal (SEA) has a positive and significant relationship with affective commitment.

$\mathrm{H}_{2}$ : The dimension of Other's Emotional Appraisal (OEA) has a positive and significant relationship with affective commitment.

$\mathrm{H}_{3}$ : The dimension of Use of Emotions (UOE) has a positive and significant relationship with affective commitment.

$\mathrm{H}_{4}$ : The dimension of Regulation of Emotions (ROE) has a positive and significant relationship with affective commitment.

\section{METHODOLOGY}

This is a survey study involving quantitative methods and Statistical Packages for 
Social Sciences (SPSS) analysis and a Structural Equation Modeling (SEM) approach through Partial Least Square (PLS) applications.

\section{A. Samples and Procedures}

The sampling method used in this study is a Non-Probability sampling technique, which utilizes a purposive based sampling technique. The respondents of this study involved five state contingents comprising Kuala Lumpur, Selangor, Johor, Sarawak and Sabah. A total of 1000 questionnaires were distributed to police officers. However, only 402 (40.2\%) of police officers participated in this survey and, of the 402 responses returned, only 372 $(37.2 \%)$ were usable.

\section{B. Instrument}

In terms of the measuring scale, the Wong and Law Emotional Intelligence Scale (WLEIS) by [li] was used to measure emotional intelligence in this study. The WLEIS scale has 16 items with four items for each of the four factors, namely SEA, OEA, UOE and ROE that can be used in the field of management studies. This instrument has high compatibility (CR), reliability of SEA (0.89), OEA (0.87), UOE (0.80) and ROE (0.88). The instruments used to test affective commitment were the questionnaires developed by [ii] known as the Allen and Meyer's Affective Commitment Scale. This questionnaire contains eight items of measurement and has high reliability with a composite reliability $(\mathrm{CR})$ value of 0.90 . The measurement instrument for data collection was in the form of a 5-point Likert scale ranging from 1 (strongly disagree) to 5 (strongly agree).

\section{RESULTS AND FINDINGS}

\section{A. Demographics}

The majority of the respondents were male (84.1\%) while the rest were female respondents. The respondents were mainly Malay (72.8\%) and Muslim (80.9\%). More than half of respondents had obtained the SPM (Malaysian Certificate of Education) as their highest academic qualification $(59.9 \%)$. The majority of the respondents' marital status was married (77.4\%). The military rank of the majority of respondents was Corporal (37.4\%). Most of the respondents have had service experience in PDRM organizations for $11-20$ years $(26.6 \%)$, salaries less than RM3000 (46.5\%) and are based in the Selangor contingent (25.5\%).

\section{B. Hypothesis Testing}

The data was assessed in a two-step process. The first step was the measurement model and the second step was the structural model [ ${ }^{\text {lxxiii }}$ ]. Table 1 below shows the summary of the relevant measurement models related to the reliability and validity of the assessment instrument. Based on Table 1, the items in the measurement model exhibited loadings that exceeded 0.5 (recommended value) ranging from a lower band of 0.644 to an upper band of 0.954 after five items had been deleted (UOE4EQ, ROE4EQ, KA5, KA7 and KA8) because these items had values below the recommended value [lxxxiii]. The composite reliability value for each construct ranged from 0.800 to 0.896 and exceeded the threshold value of 0.7 [lxxxiii]. Thus, based on Table 1, all the items used for this study demonstrated satisfactory indicator reliability.

Table 1 :Measurement Model

\begin{tabular}{|c|c|c|c|c|c|}
\hline $\begin{array}{c}\text { Model } \\
\text { Konstruk }\end{array}$ & Item & $\begin{array}{l}\text { Loadi } \\
\text { ngs }\end{array}$ & AVE & CR & $\begin{array}{c}\text { Discrimin } \\
\text { ant } \\
\text { Validity }\end{array}$ \\
\hline $\begin{array}{l}\text { Self-Emoti } \\
\text { onal } \\
\text { Appraisal } \\
\text { (SEA) }\end{array}$ & $\begin{array}{l}\text { SEA1EQ } \\
\text { SEA2EQ } \\
\text { SEA3EQ } \\
\text { SEA4EQ }\end{array}$ & $\begin{array}{l}0.856 \\
0.954 \\
0.767 \\
0.644\end{array}$ & 0.662 & $\begin{array}{l}0.88 \\
5\end{array}$ & Yes \\
\hline $\begin{array}{c}\text { Other's } \\
\text { Emotional } \\
\text { Appraisal } \\
\text { (OEA) }\end{array}$ & $\begin{array}{l}\text { OEA1EQ } \\
\text { OEA2EQ } \\
\text { OEA3EQ } \\
\text { OEA4EQ }\end{array}$ & $\begin{array}{l}0.847 \\
0.780 \\
0.869 \\
0.660\end{array}$ & 0.629 & $\begin{array}{l}0.87 \\
0\end{array}$ & Yes \\
\hline $\begin{array}{l}\text { Use of } \\
\text { Emotions } \\
\text { (UOE) }\end{array}$ & $\begin{array}{c}\text { UOE1EQ } \\
\text { UOE2EQ } \\
\text { UOE3EQ }\end{array}$ & $\begin{array}{l}0.699 \\
0.786 \\
0.665\end{array}$ & 0.501 & $\begin{array}{l}0.80 \\
0\end{array}$ & Yes \\
\hline $\begin{array}{l}\text { Regulation } \\
\text { of } \\
\text { Emotions } \\
\text { (ROE) }\end{array}$ & $\begin{array}{l}\text { ROE1EQ } \\
\text { ROE2EQ }\end{array}$ & $\begin{array}{l}0.814 \\
0.872 \\
0.846\end{array}$ & 0.713 & $\begin{array}{l}0.88 \\
2\end{array}$ & Yes \\
\hline $\begin{array}{c}\text { Affective } \\
\text { Commitme } \\
\text { nt (KA) }\end{array}$ & $\begin{array}{l}\text { KA1 } \\
\text { KA2 } \\
\text { KA3 } \\
\text { KA4 } \\
\text { KA6 }\end{array}$ & $\begin{array}{l}0.759 \\
0.678 \\
0.906 \\
0.847 \\
0.774\end{array}$ & 0.635 & 0.896 & Yes \\
\hline
\end{tabular}

For the structural model analysis, the bootstrapping function generated 5000 samples from 372 cases. The validity of the structural model was assessed using the coefficient of determination $\left(R^{2}\right)$ and path coefficients. Figure 1 demonstrates the bootstrapping of the path coefficient of each construct. Based on the results in Figure 1, the four dimensions of emotional intelligence (SEA, OEA, UOE and ROE) have a direct relationship with affective commitment where the $t$ value exceeds the value of 2.33 at a significant level of $\mathrm{p}<0.01$. Therefore, the four hypotheses of this study are accepted and supported. 


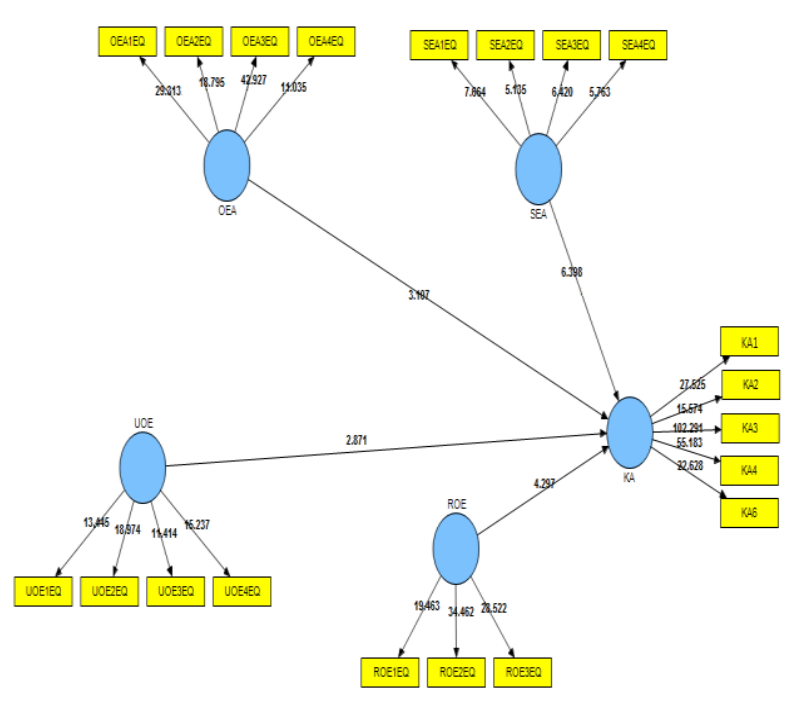

Fig 1.Bootstrappingof Path Coefficient (Direct Relationship)

Table 2 is the result of $\mathrm{H}_{1}, \mathrm{H}_{2}, \mathrm{H}_{3}$ and $\mathrm{H}_{4}$ hypothesis analysis related to the four-dimensional relationship of emotional intelligence with affective commitment (AC) in this study. The findings show that there is a positive significant relationship between the four dimensions with the variables of affective commitments, namely SEA $\rightarrow \mathrm{KA}(\mathrm{H} 1$ : $\beta=0.133, t=6.398, \mathrm{p}<0.01), \mathrm{OEA} \rightarrow \mathrm{KA}(\mathrm{H} 2: \beta=0.061, t$ $=3.107, \mathrm{p}<0.01), \mathrm{UOE} \rightarrow \mathrm{KA}(\mathrm{H} 3: \beta=0.063, t=2.871, \mathrm{p}$ $<0.01)$ and $\mathrm{ROE} \rightarrow \mathrm{KA}(\mathrm{H} 4: \beta=0.086, t=4.297, \mathrm{p}<0.01)$.

Table 2. Summary of direct relationships between variables

\begin{tabular}{ccccc}
\hline $\begin{array}{c}\text { Hypothesi } \\
\mathbf{s}\end{array}$ & $\begin{array}{c}\text { Variable } \\
\text { Relationshi } \\
\mathbf{p}\end{array}$ & $\begin{array}{c}\text { Path } \\
\text { Estimatio } \\
\boldsymbol{n}(\boldsymbol{\beta})\end{array}$ & t-value & Result \\
\hline $\mathbf{H}_{\mathbf{1}}$ & $\mathrm{SEA} \rightarrow \mathrm{KA}$ & 0.133 & $\begin{array}{c}6.398^{* *} \\
*\end{array}$ & $\begin{array}{c}\text { Supporte } \\
\mathrm{d}\end{array}$ \\
$\mathbf{H}_{\mathbf{2}}$ & $\mathrm{OEA} \rightarrow \mathrm{KA}$ & 0.061 & $\begin{array}{c}3.107 * * \\
*\end{array}$ & $\begin{array}{c}\text { Supporte } \\
\mathrm{d}\end{array}$ \\
$\mathbf{H}_{3}$ & $\mathrm{UOE} \rightarrow \mathrm{KA}$ & 0.063 & $\begin{array}{c}2.871 * * \\
*\end{array}$ & $\begin{array}{c}\text { Supporte } \\
\mathrm{d}\end{array}$ \\
$\mathbf{H}_{\mathbf{4}}$ & $\mathrm{ROE} \rightarrow \mathrm{KA}$ & 0.086 & $\begin{array}{c}4.297 * * \\
*\end{array}$ & $\begin{array}{c}\text { Supporte } \\
\mathrm{d}\end{array}$ \\
\hline Note: & Level ofSignificance $=* * * \mathrm{p}<0.01 ;$ & $* * \mathrm{p}<0.05 ;$
\end{tabular}

$*_{\mathrm{p}}<0.10 ;{ }^{\mathrm{TS}}$ Non Significant

$\mathrm{SEA}=$ Self-Emotional Appraisal; OEA $=$ Other's Emotional Appraisal; UOE=Use of Emotional;

$\mathrm{ROE}=$ Regulation of Emotional; $\mathrm{KA}=$ Affective Commitment

Table 3 shows the result of R-Squared $\left(R^{2}\right)$ and Effect Size $\left(f^{2}\right)$ analysis for each studied constructs. Based on Table 3, the coefficient of determination $R^{2}$ value for each construct fall within moderated level based on the rule of thumb which categorized value 0.75 (strong), 0.50 (moderate), and 0.25 (weak) [lxxxiii]. While for the computation process of Effect Size $\left(f^{2}\right),\left[{ }^{\text {lxxiv }}\right]$ has categorized $f^{2}$ value to $f^{2}<0.019=$ No Effect; $\quad 0.02<f^{2}<0.149=$ Weak; $\quad 0.15<f^{2}<0.349=$ Moderate; $f^{2}>0.35=$ High .

Table 3. Coefficient determination $\mathrm{R} 2$ and Effect Size $\mathrm{f}^{2}$

\begin{tabular}{cccc} 
Construct & $R^{2}$ & $f^{2}($ Effect & Level \\
Size $)$ & (Effect \\
\hline
\end{tabular}

\begin{tabular}{|c|c|c|c|c|c|}
\hline & & & & \multirow[b]{2}{*}{ Size) } \\
\hline & & Included & Excluded & & \\
\hline \multirow{4}{*}{$\begin{array}{c}\text { Emotional } \\
\text { Intelligenc } \\
\mathrm{e}\end{array}$} & SEA & 0.4101 & 0.3496 & 0.103 & Weak \\
\hline & OEA & 0.4101 & 0.3962 & 0.022 & Weak \\
\hline & UOE & 0.4101 & 0.3965 & 0.023 & Weak \\
\hline & ROE & 0.4101 & 0.3789 & 0.053 & Weak \\
\hline $\begin{array}{c}\text { Note: } \\
0.02<\mathrm{f}^{2}<0\end{array}$ & $\begin{array}{l}\text { Effect } \\
9=\mathrm{We}\end{array}$ & size & \multicolumn{2}{|c|}{$\mathrm{f}^{2}<0.019=$ No } & $\begin{array}{l}\text { Effect; } \\
\text { derate; }\end{array}$ \\
\hline
\end{tabular}

$\mathrm{f}^{2}>0.35=$ High $[$ lxxxiv $]$

$\mathrm{SEA}=$ Self-Emotional Appraisal; OEA $=$ Other's Emotional Appraisal; UOE=Use of Emotional;

$\mathrm{ROE}=$ Regulation of Emotional

\section{DISCUSSION}

The hypothesis examination of the study related to the relationship between the dimension of emotional intelligence and affective commitment and found that the emotional intelligence variable showed a positive and significant relationship with affective commitment. The results of this hypothesis test are consistent and support previous studies which obtained similar results [lxxxi,lii,lxxxii,Error! Bookmark not defined.,Error! Bookmark not defined.,xviii,Error! Bookmark not defined.,Error! Bookmark not defined.]. Specifically, the findings have supported the findings of previous studies that have been conducted in which four dimensions of emotional intelligence (SEA, OEA, UOE, ROE) have positive and significant relationships with affective commitments [lii, lxxxii, Error! Bookmark not defined., xviii].

Based on the findings of this analysis, it is clear that individuals with SEA capability and the ability to emotionally increase their level of affective commitment to the organization. Police officers will be able to increase their level of loyalty to the organization if they have the ability to understand their own emotions and develop such emotions in the work environment. Hence, the higher the level of SEA skills, the higher the level of affective commitment among police officers. Whereas the opposite can occur if the SEA dimensions of the police officers decline and directly impact the downside of the commitment of police officers and may result in higher levels of employment.

Individuals with OEA capability are able to demonstrate high levels of affective commitment. It is in line with a work environment that emphasizes teamwork among its members and requires OEAs skills on the part of police officers as their daily tasks often involve interactions between teammates and communities. An increase in the OEA skill level is seen to increase the level of loyalty among police officers towards the organization. It clearly illustrates the importance of this skill for every police officer.

In addition, individuals with the ability of UOE to perform reminding activities are found to have an impact on their commitment to the organization. This is evidenced by the results of this study which indicate that the UOE dimension has a significant positive relationship with affective commitment. In the context of this study, it can be pointed out that police officers with high levels of UOE will exhibit a

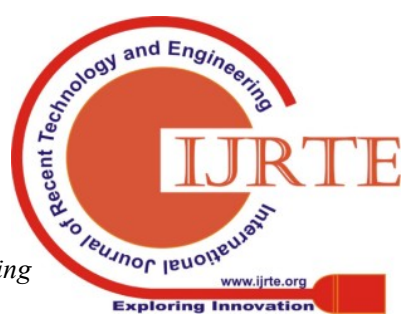


high level of affective commitment to the organization. The opposite may happen if police officers have lower UOE levels; this will result in a decline in their affective commitment. Police officers who fail to use emotions in different situations can create conflicts in themselves which will lead to personal stress. Work related stress can cause a negative impact on their commitment to the organization. UOE skills development among police officers is an important area to be addressed.

The results of this study have also proven that ROE skills have a significant positive relationship with affective commitment. It indicates that police officers who are capable of controlling their emotions are capable of recovering quickly when faced with a psychologically stressful situation. This results in an affective commitment to the organization. In light of the challenging working environments and high-pressure situations in which they often find themselves, the findings show that police officers have been trained to intelligently control their emotions.

\section{CONCLUSION}

Challenges and stresses currently faced by police organisations include grievances and complaints from the community demanding that police make drastic changes to ensure that they are more committed and relevant to the community. An increased volume of complaints, and the ensuing work stress among police officers, may also affect their level of commitment to the task of reversing the negative view the community has of their organization. Therefore, psychological elements such as emotional intelligence should be highlighted and developed because it is one of the factors that can increase the level of affective commitment among police officers.

A study of the relationship between emotional intelligence and affective commitment is still new, especially in police organizations. This study provides an important understanding for other researchers of the importance of this relationship in influencing job satisfaction, especially among police officers. It should also raise the awareness of organizational management to the need to focus on enhancing the ability of employees to harness emotional intelligence.

This study has limitations in terms of time and financial constraints and was limited the research to five policing contingents within Malaysia: Kuala Lumpur, Selangor, Johor, Sarawak and Sabah. These five contingents were chosen because they have the highest recorded membership. In addition, this study focused more on individual psychological factors, therefore, the researchers suggest that future research be conducted on external factors that are likely to impact affective commitment.

\section{ACKNOWLEDGEMENTS}

This research work is supported by the Short Term Research Grant (No:UPNM/2018/GPJP/2/SSK/4) supported by National Defence University of Malaysia

\section{REFERENCES}

[1] Mayer, J. D., and Salovey, P. (1997). What is Emotional Intelligence? In P. Salovey dan D. Sluyter (Eds.), Emotional development and
Emotional Intelligence: Educational implications (pp. 3-31). New York: Basic Books.

[2] $\left[{ }^{1}\right.$ Allen, N. J., and Meyer, J. P. (1990). The measurement and antecedents of affective, continuance, and normative commitment. Journal of Occupational Psychology, 63, 1-18.

[3] [ $\left.{ }^{1}\right]$ Mowday, R. T., Steers R. M., and Porter L. W. (1979). The measurement of organizational commitment. Journal of Vocational Behaviour, 14, 224-247.

[4] [1] Baker, R., and Ibrahim, H. I. (2017). Kecerdasan emosi dan komitmen afektif: Peranan keterikatan kerja sebagai pengantara. Jurnal Pengurusan, 49 (2017) 103-115.

[5] [ $\left.{ }^{1}\right]$ Ahmad, Z. and Halim, F. W. (2013). Pengaruh ketidakakuran sivil terhadap profesionalisme anggota PDRM, Jurnal Psikologi Malaysia. 27, 117-135.

[6] [ $\left.{ }^{1}\right]$ Baker, R., and Ibrahim, H. I. (2014). Tekanan kerja dalam organisasi kepolisan: Tinjauan dalam perspektif kecerdasan emosi. Jurnal Kemanusiaan, 12(2), 1-24.

[7] [ $\left.{ }^{1}\right]$ Yaakub, Y. and Yaacob, Z. (2018). Elemen kritikal kualiti perkhidmatan polis terhadap kepuasan pelanggan di Malaysia. Labuan Journal of Muamalat and Society, 12, 148-157.

[8] [ $\left.{ }^{1}\right]$ Hunnur, R. R., Bagali, M., and Sudarshan, S. (2014). Cause and effect of workplace stress among police personnel: An empirical study. International Journal of Management Research and Business Strategy, 3(1), 198-208

[9] [ $\left.{ }^{1}\right]$ McCutcheon, M. (2018). Emotional Intelligence and Stress of Police Officers. Doctoral dissertation, Rivier University.

[10] [ ${ }^{1}$ ]Johnson, R. R. (2012). Police officer job satisfaction: A multidimensional analysis. Police Quarterly, 15(2), 157-17

[11] [ $\left.{ }^{1}\right]$ Mohamed Sazif, M. S. (2011). The stress effect towards pdrm personnel: A case study on health problems and job satisfaction in Kedah. Master Dissertation, Universiti Utara Malaysia.

[12] [ ${ }^{1}$ ] Billing, T. K., Bhagat, R. S., Babakus, E., Krishnan, B., Ford, D. L., Srivastava, B. N., .. Nasurdin, A. M. (2014). Work-family conflict and organisationally valued outcomes: The moderating role of decision latitude in five national contexts. Applied Psychology: An International Review, 63(1), 62-95.

[13] [1] Forushani, N. Z., and Besharat, M. A. (2011). Relation between Emotional Intelligence and perceived stress among female students. Social and Behavioral Sciences, 30(0), 1109-1112.

[14] [1] Alipour, F., and Kamaee Monfared, M. (2015). Examining the relationship between job stress and organizational commitment among nurses of hospitals. Journal of Patient Safety \& Quality Improvement, $3(4), 277-280$

[15]

[16] [1] Yang, T., Guo, Y., Ma, M., Li, Y., Tian, H., and Deng, J. (2017) Job stress and presenteeism among Chinese healthcare workers: The mediating effects of affective commitment. International Journal of Environmental Research and Public Health, 14(9), 978.

[17] [1] Mardhiah, Y. (2012). Strategi daya tindak sebagai moderator dalam hubungan antara kecerdasan emosi dengan kepuasan kerja, komitmen organisasi dan kesejahteraan psikologi. Master Dissertation, Universiti Teknologi Malaysia

[18] [ $\left.{ }^{1}\right]$ Awang Besar, J. (2017). Keberkesanan pelaksanaan dasar awam di kawasan Dewan Undangan Negeri (N24) Semenyih, Selangor: Suatu pemerhatian terhadap pandangan pengundi Melayu. Jurnal Melayu, 16(2).

[19] [ ${ }^{1}$ ] Ramly, M. S. and Mansor, M. (2017).Relationship between Emotional Intelligence and Commitment to Change among Senior Administrative and Diplomatic Service (ADS) Officers in Malaysia. International Business Education Journal, 10 (1), 17-30.

[20] [ $\left.{ }^{1}\right]$ Siddiquee, N.A. (2014). Malaysia's government transformation programme: A preliminary assessment. Intellectual Discourse, 22(1) 7-31.

[21] [ $\left.{ }^{1}\right]$ Laporan Statistik Aduan Biro Pengaduan Awam Bagi Tempoh 1 Januari $\quad-\quad 31 \quad 31$ Disember 2013.http://www.pcb.gov.my/STATISTIK/2012/disember/STATISTI K\%20ADUAN\%20\%20MENGIKUT\%20NEGERI\%20(BM)[1].pdf

[22] [1]Laporan Statistik Aduan Biro Pengaduan Awam Bagi Tempoh 1 Januari - $\quad 31 \quad$ Disember 2014.http://www.pcb.gov.my/STATISTIK/2014/Kerajaan\%20Negeri $\% 20$ (Janaan\%20Muktamad).pdf

[23] ${ }^{1}{ }^{1}$ Laporan Statistik Aduan Biro Pengaduan Awam Bagi Tempoh 1 $\begin{array}{lllll}\text { Januari } & - & 31 & \text { Disember } & 2015\end{array}$ 
http://www.pcb.gov.my/STATISTIK/2015/Kerajaan\%20Negeri.pdf

[24] [ ${ }^{1}$ ] Laporan Statistik Aduan Biro Pengaduan Awam Bagi Tempoh 1 Januari Disember 2016.http://www.pcb.gov.my/STATISTIK/2016/Laman\%20Web\%2 0Statistik\%20Aduan\%20DISEMBER\%202016\%20BM.pdf

[25] [ ${ }^{1}$ ] Laporan Statistik Aduan Biro Pengaduan Awam Bagi Tempoh 1 Januari 31 Disember 2017.http://www.pcb.gov.my/STATISTIK/2017/Laman\%20Web\%2 0Statistik\%20Aduan\%20DIS\%202017\%20BM.pdf

[26] [ ${ }^{1}$ ] Lam, W. L., and Liu, Y. (2014). The identity-based explanation of affective commitment. Journal of Managerial Psychology, 29 (3), 321-340

[27] [ $\left.{ }^{1}\right]$ Marques, T., Galende, J., Cruz, P., and Portugal Ferreira, M. (2014). Surviving downsizing and innovative behaviors: A matter of organizational commitment. International Journal of Manpower, 35(7), 930-955

[28] [1] Zafir, M. M., and Sheikh Muhamad Hizam, S. K. (2014). Measuring the effect of commitment on occupational stressors and individual productivity ties. Jurnal Pengurusan, 40, 103-113.

[29] [ $\left.{ }^{1}\right]$ Indahingwati, A. (2017). Police and public image satisfaction on quality of service in corner driver's license unit. Sinergi, 7 (2), 42-57.

[30] [ ${ }^{1}$ ] Asnawi, N.H., Yunus, N. and Abd Razak, N. (2014). Assessing emotional intelligence factors and commitment towards organizational change. International Journal of Social Science and Humanity 4 (1) 5-10.

[31] [ $\left.{ }^{1}\right]$ Goleman, D. (2001). Emotional Intelligence: Issues in paradigm building. In C. Cherniss dan D. Goleman (Eds.), The Emotionally Intelligent Workplace, (13-26), Jossey-Bass: San Francisco.

[32] [ [ ] Mayer, J. D., Salovey P., and Caruso, D. R. (2008). Emotional Intelligence: New ability or eclectic traits? American Psychologist, 63(6), 503-517.

[33] [ ${ }^{1}$ ] Zeidner, M., Matthews, G., and Roberts, R. D. (2012). The emotional intelligence, health, and well-being nexus: What have we learned and what have we missed? Applied Psychology: Health and Well-Being, 4, 1-30.

[34] [ ${ }^{1}$ ] Salovey, P., and Mayer, J. D. (1990). Emotional Intelligence. Imagination Cognition and Personality, 9, 185-211.

[35] [ $\left.{ }^{1}\right]$ Goleman, D. (1995). Emotional Intelligence. New York: Bantam Books.

[36] $\left[{ }^{1}\right]$ Meisler, G., and Vigoda-Gadot, E. (2014). Perceived organizational politics, Emotional Intelligence and work outcomes: empirical exploration of direct and indirect effects. Personnel Review, 43(1), 116-135

[37] [ $\left.{ }^{1}\right]$ Uzma, H. G., and Tajammal, H. (2013). A comparative study of Intelligence Quotient and Emotional Intelligence: Effect on employees performance. Asian Journal of Business Management, 5(1), 153-162.

[38] [ $\left.{ }^{1}\right]$ Goleman, D. (1998). Working with Emotional Intelligence. New York: Bantam Books.

[39] [ $\left.{ }^{1}\right]$ Bar-On, R. (1997). The emotional quotient inventory (EQ-I). Technical manual. Toronto, Canada: Multi-Health Systems.

[40] $\left.{ }^{1}{ }^{1}\right]$ Bar-On, R. (2000). Emotional and Social Intelligence: Insights from the emotional quotient inventory (EQ-I). In R. Bar-On, dan J. D. A. Parker (Eds.). Handbook of Emotional Intelligence (pp. 363-388). San Francisco: Jossey-Bass.

[41] [1] Najeemah, M. Y. (2012). Relationship between emotional intelligence and students attitude towards co-curricular uniform bodies in Malaysia. International Journal for Educational Studies, 5(1), 95-106.

[42] [ ${ }^{1}$ ] Halimatusa'diah, S. (2011). Hubungan kecerdasan emosi dengan pencapaian akademik pelajar. Master Dissertation,Universiti Teknologi Malaysia.

43] [ $\left.{ }^{1}\right]$ Zhu, Y., Liu, C., Guo, B., Zhao, L., and Lou, F. (2015). The impact of emotional intelligence on work engagement of registered nurses: The mediating role of organisational justice. Journal of Clinical Nursing. 24(15-16), 2115-2124.

[44] [ [ ] Higgs, M., and Dulewicz, V. (2013). Antecedents of well-being: a study to examine the extent to which personality and emotiona intelligence contribute to well-being. The International Journal of Human Resource Management, 25(5), 718-735.

[45] [ $\left.{ }^{1}\right]$ Chin, S. T. S., Raman, K., Yeow, J. A., and Eze, U. C. (2012) Relationship between Emotional Intelligence and Spiritual Intelligence in nurturing creativity and innovation among successful entrepreneurs: A conceptual framework. Social and Behavioral Sciences, 57(0), 261-267.

[46] [ ${ }^{1}$ ] Por, J., Barriball, L., Fitzpatrick, J., and Roberts, J. (2011). Emotional intelligence: Its relationship to stress, coping, well-being and professional performance in nursing students. Nurse Education Today, 31(8), 855-860.
[47] [ $\left.{ }^{1}\right]$ Chesnut, S. R., and Cullen, T. A. (2014). Effects of self-efficacy, emotional intelligence, and perceptions of future work environment on preservice teacher commitment. The Teacher Educator, 49 (2), 116-132.

[48] [ $\left.{ }^{1}\right]$ Sapta, A., Hermawan, A., Hubeis, M., and Affandi, M. J. (2013). Affect of ESQ training (training of emotional intelligence and spiritual intelligence) to organizational commitment and job satisfaction International Journal of Information Technology and Business Management, 11(1), 40-54

[49] [1] Joseph, D. L., Jin, J., Newman, D. A., and O’Boyle, E. H. (2014) Why does self-reported emotional intelligence predict job performance? A meta-analytic investigation of mixed EI. Journal of Applied Psychology. Advance online publication. http://dx.doi.org/10.1037/a0037681

[50] [1] Yozgat, U., Yurtkoru, S., and Bilginoglu, E. (2013). Job stress and job performance among employees in public sector in Istanbul: Examining the moderating role of emotional intelligence. Social and Behavioral Sciences, 75(0), 518-524.

[51] [1] Abraham, R. (2000). The role of job control as a moderator of emotional dissonance and emotional intelligence-outcome relationships. The Journal of Psychology, 134(2), 169-184.

[52] [1] Wong, C.-S., and Law, K. S. (2002). The effects of leader and follower emotional intelligence on performance and attitude: An exploratory study. The Leadership Quarterly, 13(3), 243-274.

[53] [1] Aydogmus, C. (2018) Knowledge workers' job performance: The roles of emotional intelligence and affective commitment. Journal of Social Research and Behavioral Sciences, 4(5), 72-83.

[54] [1] Noorbakhsh, S. N., Besharat, M. A., and Zarei, J. (2010) Emotional Intelligence and coping styles with stress. Social and Behavioral Sciences, 5(0), 818-822.

[55] [ ${ }^{1}$ ] Daus, C. S., and Brown, S. (2012). Chapter 11: The emotion work of police. In Neal, M. Ashkanasy, Charmine, E. J. Hartel, Wilfred, J. Zerbe (Ed.), Experiencing and Managing Emotions in the Workplace (Research on Emotion in Organizations, Volume 8) Emerald Group Publishing Limited, pp.305-328.

[56] [ $\left.{ }^{1}\right]$ Hoque, Z., Arends, S., and Alexander, R. (2004). Policing the police service: a case study of the rise of "new public management" within an Australian police service. Accounting, Auditing and Accountability Journal, 17(1), 59-84.

[57] [1] George, C. (2014). Retaining professional workers: What makes them stay? Employee Relations, 37, 102-121.

[58] [ 1 ]Meyer, J. P., and Allen, N. J. (1991). A three-componen conceptualization of organizational commitment. Human Resource Management Review, 1, 61-89.

[59] [ $\left.{ }^{1}\right]$ Meyer, J. P., and Herscovitch, L. (2001). Commitment in the workplace: Toward a general model. Human Resources Management Review, 11, 299-326.

[60] $\left[^{1}\right]$ Yahaya, A., Yahaya, N., Maalip, H., and Ramli, J. (2012). The relationship between the occupational stress, organizational commitment and job satisfaction with organizational citizenship behavior. Archives Des Sciences, 65, 55-73

[61] [ $\left.{ }^{1}\right]$ Bergman, M. E. (2006). The relationship between affective and normative commitment: Review and research agenda.Organizational Behavior Journal, 27(5), 645-663.

[62] [ $\left.{ }^{1}\right]$ Meyer, J. P., Becker, T. E. and Van Dick, R. (2006). Social identities and commitments at work: Toward an integrative model. Journal of Organizational Behavior, 27(5), 665-683.

[63] [ $\left.{ }^{1}\right]$ Nasina, M. D., and Doris, K. P. P. (2011). The workplace spirituality and affective commitment among auditors in big four public accounting firms: Does it matter? Journal of Global Management, 2(1), 216-226.

[64] [ $\left.{ }^{1}\right]$ Boles, J., Madupalli, R., Rutherford, B., and Wood, J. A. (2007) The relationship of facets of salesperson job satisfaction with affective organizational commitment. Journal of Business and Industrial Marketing, 22(5), 311-321.

[65] [ ${ }^{1}$ ] Malik, O. F., Waheed, A., and Malik, K. (2010). The mediating effects of job satisfaction on role stressors and affective commitment International Journal of Business and Management, 5(11), 223-235.

[66] [ $\left.{ }^{1}\right]$ Khan, T. I., Jam, F. A., Akbar, A., Khan, M. B., and Hijazi, S. T. (2011). Job involvement as predictor of employee commitment: Evidence from Pakistan. International Journal of Business and Management, 6(4), 252.

[67] $\left[{ }^{1}\right]$ Lam, L. W. (2012). Impact of competitiveness on salespeople's commitment and performance. Journal of Business Research 65 (9), 1328-1334.

[68] [1] Rahayu, T., Salleh, Y., and Muhammad Nizam, Z. (2014). 
"I'm loving it!" What makes the successful entrepreneur affectively committed to entrepreneurial performance. The Journal of Applied Management and Entrepreneurship, 19(2), 27-52.

[69] [ $\left.{ }^{1}\right]$ Allen, N. J., and Meyer, J. P. (1996). Affective, continuance, and normative commitment to the organization: An examination of construct validity. Journal of Vocational Behavior, 49, 252-276.

[70] [ ${ }^{1}$ ] Wang, Q., Weng, Q., McElroy, J. C., Ashkanasy, N. M., and Lievens, F. (2014). Organizational career growth and subsequent voice behavior: The role of affective commitment and gender. Journal of Vocational Behavior, 84(3), 431-441.

[71] [ $\left.{ }^{1}\right]$ Brunetto, Y., Teo, S. T. T., Shacklock, K., and Farr-Wharton, R. (2012). Emotional Intelligence, job satisfaction, well-being and engagement: Explaining organisational commitment and turnover intentions in policing. Human Resource Management Journal, 22(4), 428-441.

[72] [ $\left.{ }^{1}\right]$ Kalantarkousheh, S. M., Sharghi, N., Soleimani, M., and Ramezani, S. (2014). The role of spiritual intelligence on organizational commitment in employees of Universities in Tehran Province, Iran. Social and Behavioral Sciences, 140(0), 499-505.

[73] [ $\left.{ }^{1}\right]$ Xerri, M. J., and Brunetto, Y. (2013). Fostering innovative behaviour: The importance of employee commitment and organisational citizenship behaviour. The International Journal of Human Resource Management, 24(16), 3163-3177.

[74] [ $\left.{ }^{1}\right]$ Cooper-Hakim, A., and Viswesvaran, C. (2005). The construct of work commitment: testing an integrative framework. Psychological Bulletin, 131(2), 241-59.

[75] [ $\left.{ }^{1}\right]$ Wallace, M. J. (2018). A quantitative explanatory analysis examining the moderating effect of generational cohort on emotional intelligence and organizational commitment among nonprofit employees. Doctoral dissertation, Capella Universit

[76] [1] Fatima, A., Imran, R., Ahmed Khan, A., Ahmed Khan, H. (2015). Awakening individual's changecommitment: The role of emotional and spiritual intelligence in health sector in Pakistan.Journal of Applied Environment and Biological Science, 5(1), 14-19

77] [ $\left.{ }^{1}\right]$ Joseph, D. L., and Newman, D. A. (2010). Emotional intelligence: An integrative meta-analysis and cascading model. Journal of Applied Psychology, 95, 54-78.

[78] [ ${ }^{1}$ ] Njoroge, C. N., and Yazdanifard, R. (2014). The impact of social and emotional intelligence on employee motivation in a multigenerational workforce. Global Journal of Management \& Business Research: A Administration and Management, 14(3), 31-36.

[79] [ $\left.{ }^{1}\right]$ Bhalerao, H., \& Kumar, S. (2016). Role of emotional intelligence in leaders on the commitment level of employees: A study in information technology and manufacturing sector in India. Business Perspectives \& Research, 4(1), 41-53.

[80] [ $\left.{ }^{1}\right]$ Nurharani S., and Norshidah, N. (2014). Teacher's commitment and emotional intelligence: evidence from Malaysian schools International Journal of Science Commerce Humanities, 2(3), 2-3

[81] [ ${ }^{1}$ ] Shafiq, M., and Rana, A. R. (2016). Relationship of emotional intelligence to organizational commitment of college teachers in Pakistan. Eurasian Journal of Educational Research, 62, 1-14.

[82] [ ${ }^{1}$ ] Ayala, E. M. V. (2018). Examining the relationship between the emotional intelligence of principals as perceived by teachers and teachers' organizational commitment. Doctoral Dissertation, Our Lady of the Lake University, San Antonio, Texas

[83] $\left[{ }^{1}\right]$ Bennett, D. R. (2011). Examining the relationship between emotional intelligence of managers and organizational commitment of subordinates. Doctoral Dissertation. Northcentral University.

[84] [ ${ }^{1}$ ] Hair, J. F., Hult, G. T. M., Ringle, C. M., and Sarstedt, M. (2014). A Primer on Partial Least Squares Structural Equation Modeling (PLS-SEM). Thousand Oaks, CA: Sage.

[85] $\left.{ }^{1}\right]$ Cohen, J. (1988). Statistical power analysis for the behavioral sciences (2nd ed.). Hillsdale, NJ: Lawrence Earlbaum Associates

My name is Rogis Baker, I am from Faculty of Defence Studies \& Management, Universiti Pertahanan Nasional Malaysia, 57000 Sungai Besi, Kuala Lumpur Malaysia my area of research is defense and crime management.

My name is Amar Hisham Jaaffar,I am associated with College of Business Management \& Accounting, Universiti Tenaga Nasional, 26810 Muadzam Shah, Pahang, Malaysia. my area of research is defense and crime management.
My name is Hasimi Sallehuddin, I am attached with Faculty of Information Science \& Technology, Universiti Kebangsaan Malaysia, 43600 Bangi, Selangor, Malaysia my area of research is defense and crime management. 